\title{
Factors Affecting Foreign Direct Investment: Evidence on Tay Ninh Province
}

\author{
Thinh Quoc TRAN ${ }^{1}$, Tuan Anh DANG ${ }^{2}$, Ngoc Anh Thu TRAN ${ }^{3}$
}

Received: June 19, 2020 Revised: July 05, 2020 Accepted: August 10, 2020

\begin{abstract}
The purpose of this paper is to examine the impact of consumer price index, infrastructure, human resources, trade openness, and private credit on the attraction of foreign direct investment (FDI) in Tay Ninh province as well as to emphasize the important role of FDI in economic growth of developing areas. The research data was collected from Tay Ninh Statistical Office with 80 samples of a 20 -year period from 2000 to 2019. Also, OLS regression method using Eviews software was employed to analyze the data obtained. The findings revealed that human resources, infrastructure and private credit have a positive and significant impact on FDI attraction in Tay Ninh province, while consumer price index was proven to affect FDI attraction negatively. Accordingly, competent authorities of Tay Ninh province should focus on stabilizing prices as well as implementing policies for developing local human resources and attracting high-quality personnel from foreign countries. Tay Ninh province also needs to pay more attention to information technology investment for synchronous development of infrastructure. Moreover, the State Bank of Tay Ninh branch needs to consider more credit sources to provide support packages for businesses, creating a strong basis for establishments to attract FDI for the province's economic development.
\end{abstract}

Keywords: Foreign Direct Investment, Human Resource Practices, Infrastructure Development, Private Credit, Consumer Price Index

JEL Classification Code: F21, F23, F43

\section{Introduction}

Tay Ninh province is located in the Southeast region of Vietman, which is one of the Southern key economic zones. Over the years, the province has made great efforts in attracting foreign direct investment (FDI) and achieved certain results. However, comparing with the common ground, the value of FDI in the province is not as expected. Design and implementation of projects are still inadequate. Moreover, multiple projects that have been suspended or

${ }^{1}$ First Author. Associate Professor, Faculty of Accounting and Auditing, Industrial University of Ho Chi Minh City, Vietnam. Email: tranthinhktkt@gmail.com

${ }^{2}$ Lecturer, Faculty of Economics, Ho Chi Minh City Open University, Vietnam. Email: anhtuancpa@gmail.com

${ }^{3}$ Corresponding Author. Tax Associate, PwC (Vietnam) Limited, Vietnam [Postal address: Ngo Duc Ke Street, Ward 12, Binh Thanh District, Ho Chi Minh City, 70000, Vietnam] Email: anhthutn.buh@gmail.com

(c) Copyright: The Author(s)

This is an Open Access article distributed under the terms of the Creative Commons Attribution Non-Commercial License (https://creativecommons.org/licenses/by-nc/4.0/) which permits unrestricted non-commercial use, distribution, and reproduction in any medium, provided the original work is properly cited. withdrawn, which poses many challenges for the province (People's Committee of Tay Ninh Province, 2019).

FDI attraction is essentially important for the national development, in particular, it is considered as a key factor in solving the economic crisis in developing countries (Nantharath and Kang, 2019). Theoretically, FDI can aid in reducing the size of shadow economy through improving institutional quality, boosting economic growth and creating employment (Bui, 2020). Therefore, many studies, both domestic and abroad, have been focusing on identifying the impact factors of FDI so that appropriate policies could be timely put in place. Research in this regard is divided up into three geographical characteristics, including those usually carried out in one specific nation or group of emerging countries or certain regions. Those pertaining to the first type are mentioned by Mughal and Akram (2011); Xin et al. (2012); Mfinanga (2018); Nantharath and Kang (2019). While that of the second type are of Jadhav (2012) and Groh and Wich (2012). Typical examples of the last type are those of Tintin (2013); Hunady and Orviska (2014); and Makhavikova (2015), carried out in European countries. Regarding Vietnam, certain studies were conducted on separate provinces such as Nguyen and Nguyen (2007); 
Wang and Balasubramanyam (2011); Le and Nguyen (2017) and other studies of Le (2015), Nguyen (2015), Ta et al. (2020) and Ngo et al. (2020).

The demand for FDI capital has become more urgent than ever especially for developing countries during the reform period (Amirahmadi and $\mathrm{Wu}, 1994$ ) as foreign investors bring access to available capital needed, advanced technology and more importantly, the access to international markets. In Vietnam, the competition between provinces in attracting FDI capital is reflected in more flexible and open policies and mechanisms (Vu, Le and Vo, 2007). As a typical example, Tay Ninh is one of the key provinces with certain potentials and strengths that gradually expand its activities to attract FDI. To better assess the current economic condition of Tay Ninh province, the paper addresses some of the province's specific characteristics based on consulting with provincial leaders. And thus, this study wish to make more contribution to the province's improvement in the investment environment and its sustainable development.

\section{Literature Review}

\subsection{Theoretical Perspective}

The theory of advantages of ownership, location and internalization (OLI) is also named as eclectic theory, which refers to the advantages of ownership, geographic location and inland. Eclectic is one of the economic theories proposed by Dunning (1979). This theory explains the advantages of national ownership and organizations owning large-scale capital will have the opportunity to develop and increase economic resources in expanding outward scope. The geographical advantages expressed by the natural resources, a particular nation or an organization are considered as competitive advantages to utilize, exploit, or form a basis for collecting the resources from outside. The advantages of localization represent the internal strengths of the nation itself or the organization by taking advantage of internal resources for development and creating their own strengths to ensure autonomy and avoid dependence (Dunning, 1979). This theory is applied in the model to explain the factors related to inherent advantages of Tay Ninh's resources, which affect FDI attraction.

\subsection{Previous Studies}

There are case studies focusing on typical nations, see Mughal and Akram (2011); Xin et al. (2012); Mfinanga (2018); and Nantharath and Kang (2019). Specifically, Mughal and Akram (2011) studied the factors affecting the FDI attraction of Pakistan in the period from 1984 to 2008. The research results show that GDP affects FDI attraction positively, while the exchange rate adversely affects FDI attraction and corporate income tax has no effect. In Malaysia, Xin et al. (2012) studied factors affecting FDI attraction during 1996-2010. Similarly, the results show that GDP has a positive influence on FDI attraction. Furthermore, trade openness and inflation also affect FDI attraction positively, while infrastructure has no effect. Unlike Mughal and Akram's (2011) results, exchange rates in Malaysia's case affect FDI attraction positively. This result is also supported by Mfinanga (2018) in Tanzania during 1990-2015. However, GDP has a negative effect in this case, while trade openness and the consumer price index (CPI) have no effect. However, identical to Xin et al. (2012)'s research, the results obtained from the study by Nantharath and Kang (2019) using the vector autoregressive model also indicate a positive relationship between trade openness and FDI attraction in the Laos, whereas human capital and institutional quality have negative effects on the economic growth.

Regarding emerging countries, Jadhav (2012) studied the factors affecting FDI attraction in Brazil, Russia, India, China and southern Africa in the period of 2000-2009. The research results show that trade openness, GDP and CPI have a positive impact on FDI attraction, while other factors related to natural resources have an opposite effect and the provisions of law and politics have no effect on FDI attraction. Similarly, Groh and Wich (2012)'s results show that GDP, infrastructure and commercial openness affect FDI attraction positively as the authors employed a sample of 127 emerging economies from 2007 to 2008.

Some studies focusing on European countries are Tintin (2013); Hunady and Orviska (2014); and Makhavikova (2015). Using a sample of Eastern Europe in the period of 1996-2009, Tintin (2013)'s results show that factors, including GDP, trade openness, economic freedom, and political stability, impact FDI attraction positively, while the geographical distance such as investment countries, investment places as well as civil status have insignificant impact. Hunady and Orviska (2014) employed a sample of 27 countries and territories of Europe in the period of 2004-2011. Similarly, the results show that GDP, public debt, and trade openness affect FDI attraction positively. In contrast, crisis situation and labor cost affect FDI attraction negatively, while the other factors have no impact, such as CPI, unemployment rate, tax rate of import and export tax. Also, Mavavikova (2015)'s results for the period 19922013 show that GDP, trade openness, and population have a positive correlation with FDI attraction, while infrastructure, utility costs, politics, and culture have no significant impact.

Regarding Vietnam, a few studies have been carried out such as Nguyen and Nguyen (2007); Wang and Balasubramanyam (2011); Le and Nguyen (2017), Ta et al. (2020) and Ngo et al. (2020). Also, some studies by Le (2015); Nguyen (2015) examined separate provinces. For the former type, Nguyen and Nguyen (2007) examined the influence of 
factors on Vietnam's FDI attraction in 1988-2006. The results of the regression analysis show that GDP, human resources and infrastructure have a positive effect on Vietnam's FDI attraction, while government policy has no effect. Wang and Balasubramanyam (2011) studied the factors affecting FDI attraction in 58 provinces of Vietnam during 1995-1999. Similarly, the results indicate that the GDP growth rate and human resources have a significant influence on Vietnam's FDI attraction, while the infrastructure has no effect.

Le and Nguyen (2017) studied the factors affecting FDI attraction of 63 provinces in 2011-2014, and employed the spatial econometric model to determine the impact factor. The results show that market size, labor quality, the infrastructure, degree of concentration, and the degree of urbanization, have a positive effect, while labor costs has a negative effect on FDI attraction. Ta et al. (2020) used autoregressive distributed lag model (ARDL) to test the factors affecting Korean FDI into Vietnam, from 1995 to 2017. The results show that factors such as low wages, trade openness, and government policy impact Korean FDI into Vietnam positively in the long term.

More recently, Ngo et al. (2020), using generalized methods of moments (GMM) and pooled mean group (PMG) to analyze the determinants affect FDI attraction in Vietnam during 2000-2019 show that the factors with positive influences on FDI attraction are market size, labor force, macroeconomic policy, macroeconomic stability, and skilled labor. Regarding studies related to separate provinces, Le (2015) conducted a survey on 37 FDI enterprises in Thanh Hoa province between 2001 and 2012. The results show that factors related to resources, infrastructure and finance have a significantly positive influence on FDI attraction; meanwhile, cultural and social factors have little influence. Nguyen (2015) considered the factors affecting FDI attraction in Cuu Long province in 2014. The author employed linear regression method and the results indicate that trade openness, number of telephone subscribers, labor force, and private credit affect FDI attraction in this province positively, while public debt is adversely correlated.

\section{Methodology}

\subsection{Data}

The paper uses quantitative methods by OLS regression with the support of Eview software. The research data is aggregated from Tay Ninh Statistical Office with 80 samples of all quarters in 20 years from 2000 to 2019.

\subsection{Research Model and Measurement}

The research model consists of five main variables, which are chosen based on previous studies' results and a survey conducted by economic experts working at the Tay Ninh Department of Planning and Investment. The previous studies of Vietnam have not included private credit and consumer price index, however, according to experts in Tay Ninh province, these factors should be considered. In total, there are five important factors as below:

\section{Consumer price index (PRICE)}

The consumer price index is usually used in previous studies as a proxy for a country's macroeconomic stability. This indicator is believed to reflect the stable development of the national economy, which is also considered by most previous studies aboard. A majority of results have shown that this factor affects FDI attraction negatively (Jadhav, 2012), therefore, the proposed hypothesis is:

H1: Consumer price index has a negative impact on FDI attraction in Tay Ninh province.

\section{Infrastructure (INFRAS)}

Infrastructure is the foundation for production and business activities. The development of this factor indicates how convenient the operational environment is so that initial investment costs could be minimized and FDI attraction is therefore enhanced. Most of the authors used this variable in their studies and most of the results also suggest that infrastructure is reflected in the criteria of telephone, Internet and telecommunication subscribers that have a positive impact on FDI attraction (Nguyen and Nguyen, 2007; Groh and Wich, 2012; Makhavikova, 2015; Le, 2015; Le and Nguyen, 2017). Therefore, the proposed hypothesis is:

H2: Infrastructure has a positive impact on FDI attraction in Tay Ninh province.

\section{Human resources (HUMAN)}

The quality of human resources is expressed through its stability and diversity. An abundant human resource with qualified and skilled laborers is a promising condition for attracting FDI. It can be seen that this factor had been mentioned in most of the previous study and it is widely believed that this factor has a positive impact on FDI attraction (Nguyen and Nguyen, 2007; Wang and Balasubramanyam, 2011; Nguyen, 2015; Makhavikova, 2015; Le and Nguyen, 2017; Ngo et al., 2020). Therefore, the proposed hypothesis is:

H3: Human resources have a positive impact on FDI attraction in Tay Ninh province

\section{Trade openness (TRADE)}

Trade openness is often expressed through the proportion of import-export value to total GDP. This shows that a country or region with a large export and import value has 
more potentials and advantages in external trade, which usually attracts the attention of FDI enterprises. Similar to the factors of infrastructure or human resources, most studies considered this factor and most research results show the positive impact of this factor on FDI attraction (Xin et al., 2012; Nguyen, 2015; Le and Nguyen, 2017; Nantharath and Kang, 2019; Ta et al., 2020). Therefore, the proposed hypothesis is:

H4: Trade openness has a positive impact on FDI attraction in Tay Ninh province.

\section{Private credit (CREDIT)}

Private credit reflects the capital resources used for economic activities, which is also a reflection of the mobilization and use of capital by the non-state sector and development potential of the economic sectors. This factor is of interest to previous studies, however, the results of foreign studies do not record the impact of this variable. It is possible that this factor may be suitable for the characteristics and conditions of the Vietnamese economy (Le, 2015; and Nguyen, 2015). Therefore, the proposed hypothesis is:
H5: Private credit has a positive impact on FDI attraction in Tay Ninh province

Based on the above discussions, the proposed regression model is as follows:

$$
\begin{aligned}
\text { FDI }= & \beta_{0}+\beta_{1} * \text { PRICE }+\beta_{2} * \text { INFRAS }+\beta_{3} * \text { HUMAN }+ \\
& \beta_{4}{ }^{*} \text { TRADE }+\beta_{5}{ }^{*} \text { CREDIT }+\varepsilon
\end{aligned}
$$

\section{Results and Discussion}

\subsection{Descriptive Statistics}

In general, mean and median values of every variable are relatively similar, and standard deviation of each variable is also negligible. Regarding dependent variable, FDI has an average of 7.379, which is relatively close to the maximum and minimum value. This shows that the FDI attraction in Tay Ninh province over the period has experienced no significant changes. The average values of the independent variables, including PRICE, HUMAN, TRADE, CREDIT and INFRAS are 101.686; 6.931; 6.412; 0.392 and 5.625, which are quite similar to median values, indicating that there are no significant changes during the research period.

\begin{tabular}{|c|c|c|c|}
\hline Variable symbol & Variable name & Measurement & Expected signs \\
\hline FDI & $\begin{array}{l}\text { Foreign Direct } \\
\text { Investment }\end{array}$ & $\begin{array}{l}\text { Logarithm of the Province's foreign direct } \\
\text { investment }\end{array}$ & \\
\hline PRICE & Consumer price index & Consumer price index of the Province (\%) & - \\
\hline INFRAS & The infrastructure & $\begin{array}{l}\text { Logarithm of the total telephone subscribers of } \\
\text { the Province }\end{array}$ & + \\
\hline HUMAN & Human Resources & Logarithm of the total population of the Province & + \\
\hline TRADE & Trade openness & $\begin{array}{l}\text { Logarithm of the import and export value of the } \\
\text { Province }\end{array}$ & + \\
\hline CREDIT & Private credit & $\begin{array}{l}\text { Logarithm of credit outstanding of commercial } \\
\text { banks in the Province }\end{array}$ & + \\
\hline
\end{tabular}

Table 1: Computation and expected signs of variables in the model

Table 2: Descriptive statistics for variables included in the model

\begin{tabular}{|l|c|c|c|c|c|c|}
\hline VARIABLES & FDI & PRICE & HUMAN & TRADE & CREDIT & INFRAS \\
\hline Mean & 7.379402 & 101.6879 & 6.931235 & 6.411858 & 0.392140 & 5.625376 \\
\hline Median & 7.688049 & 101.2344 & 6.966967 & 6.964712 & 0.382097 & 6.761237 \\
\hline Maximum & 8.921324 & 110.9956 & 7.026427 & 8.740497 & 0.650500 & 7.392032 \\
\hline Minimum & 4.768564 & 97.72530 & 5.502278 & 3.079614 & 0.235658 & 2.169054 \\
\hline Std. Dev. & 1.030591 & 2.297306 & 0.201380 & 1.860196 & 0.088100 & 1.976171 \\
\hline Observations & 80 & 80 & 80 & 80 & 80 & 82 \\
\hline
\end{tabular}


Table 3: Correlation coefficient matrix

\begin{tabular}{|l|c|c|c|c|c|c|}
\hline VARIABLES & FDI & PRICE & INFRAS & HUMAN & TRADE & CREDIT \\
\hline FDI & 1.000000 & & & & & \\
\hline PRICE & 0.426726 & 1.000000 & & & & \\
\hline INFRAS & 0.314813 & 0.196208 & 1.000000 & & & \\
\hline HUMAN & 0.435491 & 0.251170 & 0.473512 & 1.000000 & & \\
\hline TRADE & 0.243278 & 0.379184 & 0.451103 & 0.593436 & 1.000000 & \\
\hline CREDIT & 0.510912 & 0.212349 & 0.607123 & 0.235561 & 0.431789 & 1.000000 \\
\hline
\end{tabular}

Table 4: Regression results

\begin{tabular}{|l|c|c|c|c|}
\hline Variable & Coefficient & Std. Error & t-Statistic & Prob. \\
\hline PRICE & -0.051104 & 0.018384 & -2.779839 & 0.0071 \\
\hline HUMAN & 0.627434 & 0.236452 & 2.653536 & 0.0099 \\
\hline TRADE & 0.461934 & 0.014278 & 2.102276 & 0.2012 \\
\hline INFRAS & 0.385785 & 0.027174 & 14.19691 & 0.0000 \\
\hline CREDIT & 2.750774 & 0.591402 & 4.651272 & 0.0000 \\
\hline C & 4.978338 & 2.274598 & 2.188667 & 0.0321 \\
\hline R-squared & 0.896836 & Mean dependent var & 7.379402 \\
\hline Adjusted R-squared & 0.890677 & S.D. dependent var & 1.030591 \\
\hline S.E. of regression & 0.340754 & Akaike info criterion & 1.751605 \\
\hline Sum squared resid & 7.779605 & Schwarz criterion & 1.909707 \\
\hline Log likelihood & 22.05780 & \multicolumn{2}{|c|}{ Hannan-Quinn criter. } & 3.814546 \\
\hline F-statistic & 145.6135 & \multicolumn{2}{|c|}{ Durbin-Watson stat } & 2.180715 \\
\hline Prob(F-statistic) & 0.000000 & \multicolumn{3}{|l}{} \\
\hline
\end{tabular}

\subsection{Correlation Analysis}

The results of correlation analysis of variables in the model are presented in Table 3. All factors have a relatively close correlation. This is reflected through independent variables with correlation coefficients ranging from 0.24 to 0.51 and there are cohesion relationships between the independent variables with correlation coefficients ranging from 0.19 to 0.60 . In addition, the coefficients do not exceed 0.8 , so there is no polyline collinearity (VIF).

\subsection{Regression Analysis}

The paper uses linear correlation to check the correlation relationship corresponding to each hypothesis set out earlier (Table 4). The results of the correlation test will be the basis for considering the suitability of the aforementioned hypotheses.
Based on the results, the relevance of the model is $89 \%$, which shows that the dependent variable can be explained $89 \%$ by the independent variables. Regression results show that there are four variables with significance level less than $1 \%$ and the general significance level of the model is also less than $1 \%$. Of the four impact factors, only the consumer price index has a negative effect on FDI, while human resources, infrastructure and private credit affect FDI positively. Accordingly, the impact factors on FDI attraction in Tay Ninh province can be generalized through the linear regression equation as follows:

\section{FDI $=4.98-0.05 *$ PRICE $+0.63 *$ HUMAN $+0.39 *$ INFAS $+2.75^{*}$ CREDIT}

\subsection{Discussion}

The research results are similar to those of previous foreign studies (Jadhav, 2012; Groh and Wich, 2012; 
Makhavikova, 2015) as well as those in Vietnam (Nguyen and Nguyen, 2007; Wang and Balasubramanyam, 2011; Nguyen, 2015; Le, 2015; Le and Nguyen, 2017; Ngo et al., 2020). Also, these results are fully explainable by the theories of Dunning (1979) regarding inherent advantages of regional resources. The new point of this study is that consumer price index and private credit are proven to have an influence on the Province's FDI attraction. According to the regression results, there are four variables, including consumer price index (PRICE), human resources (HUMAN), infrastructure (INFRAS), and private credit (CREDIT), that have an impact on FDI attraction in Tay Ninh province, of which only the consumer price index (PRICE) has an opposite effect, while the remaining three variables have a negative correlation.

\section{Conclusion and Policy Implication}

\subsection{Conclusion}

Attracting investment has important implications for the development of Tay Ninh province, in which foreign capital is one of the most important economic resources besides the internal resources of the province. Basing on the evaluation of the Tay Ninh's FDI attraction process in the past 20 years from 2000 to 2019 , it is necessary to consider four key factors, which are the consumer price index, human resources, infrastructure, and private credit when making policies. Accordingly, competent authorities of Tay Ninh province should focus on controlling prices to avoid fluctuations as well as implementing policies for developing local human resources and attracting high-quality personnel from foreign countries. Tay Ninh province also needs to pay more attention to information technology investment for synchronous development of infrastructure. Moreover, the State Bank of Tay Ninh branch needs to consider more credit sources to provide support packages for businesses, creating a strong basis for establishments to attract FDI for the province's economic development.

\subsection{Policy Implication}

For the consumer price index (PRICE), which is a proxy for macroeconomic stability and regarded as an important issue in attracting capital, a high consumer price index is a sign of instability in the national economy. Therefore, the Department of Industry and Trade of Tay Ninh province should issue appropriate policies regarding price subsidy and stabilization in order to maintain the appropriate consumer price index level.

Regarding human resources factor (HUMAN), the Department of Education and Training as well as the
Department of Health of the Province need to pay more attention to the quality of human resources via enhancing the education quality at all levels as well as enhancing the quality of health care services. In addition, the Department of Labor, War Invalids and Social Affairs of the Province should also have policies to attract workers, especially highquality personnel to create an abundant, qualified and skilled workforce. Furthermore, more training programs should be carried out to improve the quality of human resources of Tay Ninh province.

In terms of infrastructure (INFRAS), the Department of Information and Communications of the province should pay attention to information technology investment through telephone, Internet and telecommunication subscribers, in which information technology development is concerned to meet the needs of FDI enterprises.

For private credit (CREDIT), the Tay Ninh branch of the State Bank should promote private credit through support packages so that businesses can expand their operating activities. Along with this, more preferential policies should be put in place to provide businesses with timely capital support. Also, the Province should pay more attention to the characteristics of businesses' activities so that corresponding mechanisms and policies could be timely set up to meet the typical capital demand of such businesses.

\section{References}

Amirahmadi, H., \& Wu, W. (1994). Foreign Direct Investment in Developing Countries. The Journal of Developing Areas, 28(2), 167-190.

Nguyen, A. N., \& Nguyen, T. (2007). Foreign direct investment in Vietnam: An overview and analysis the determinants of spatial distribution across provinces. MPRA Paper No. 1921, 1-67. https://mpra.ub.uni-muenchen.de/1921/

Bui, N. H. (2020). Effects of Foreign Direct Investment and Quality of Informal Institution on the Size of the Shadow Economy: Application to Vietnam. Journal of Asian Finance, Economics and Business, 7(5), 73-80. https://doi.org/10.13106/jafeb.2020. vol7.no5.073

Dunning, J. H. (1979). Explaining Changing Patterns of International Production: In Defence of the Eclectic Theory. Oxford Bulletin of Economics and Statistics, 41(4), 269-295.

Groh, A. P., \& Wich, M. (2012). Emerging economies' attraction of foreign direct investment. Emerging Markets Review, 13(2012), 210-229. DOI: 10.1016/j.ememar.2012.03.005

Hunady, J., \& Orviska, M. (2014). Determinants of Foreign direct investment in EU countries - Does corporate taxes really matter? Procedia Economics and Finance, 12(2014), 243-250. DOI: $10.1016 / \mathrm{S} 2212-5671(14) 00341-4$

Jadhav, P. (2012). Determinants of foreign direct investment in BRICSeconomies: Analysis of economic, institutional and 
political factor. Procedia - Social and Behavioral Sciences, 37(2012), 5-14. DOI: 10.1016/j.sbspro.2012.03.270

Le, H. B. H. (2015). Determinant of the factors affecting Foreign Direct Investment (FDI) flow to Thanh Hoa province in Vietnam. Procedia - Social and Behavioral Sciences, 172 (2015), 26-33.

Makhavikova, H. (2015). The Determinants of FDI in the Central and Eastern Europe. EIRP Proceedings, 10(2015). Retrieved from: http://www.proceedings.univ-danubius.ro/index.php/ eirp/article/view/1639/1617

Mfinanga, P. I. (2018). Determinants of Foreign Direct Investment Inflow in Tanzania. Global Journal of Human-Social Science: Economics, 18(1), 38-56.

Mughal, M. M., \& Akram, M. (2011). Does market size affect FDI? The Case of Pakistan. Interdisciplinary Journal of Contemporary Research In Business, 2(9), 237-247.

Nantharath, P., \& Kang, E. (2019). The Effects of Foreign Direct Investment and Economic Absorptive Capabilities on the Economic Growth of the Lao People's Democratic Republic. Journal of Asian Finance, Economics and Business, 6(3) 151-162. https://doi.org/10.13106/jafeb.2019.vol6.no3.151

Ngo, N. M., Cao, H. H., Nguyen, N. L., \& Nguyen, N. T. (2020). Determinants of Foreign Direct Investment: Evidence from Vietnam. Journal of Asian Finance, Economics and Business, 7(6), 173-183. https://doi.org/10.13106/jafeb.2020.vol7.no6.173

People's Committee of Tay Ninh Province. (2019). Summary report on 25 years of FDI attraction. Tay Ninh, Vietnam: People's Committee of Tay Ninh Province.

Nguyen, P. K. (2015). Reasons why the Mekong Delta does not attract foreign direct investment. Journal of Science of Ho Chi
Minh City Open University, 5(44). Ho Chi Minh City, Vietnam: Ho Chi Minh City Open University. [Vietnamese]

Ta, L. V., Le, H. Q., Nguyen, T. L. H., Phan, T. T., \& Do, D. A. (2020). Investigating Foreign Direct Investment Attractive Factors of Korean Direct Investment into Vietnam. Journal of Asian Finance, Economics and Business, 7(6), 117-125. https:// doi.org/10.13106/jafeb.2020.vol7.no6.117

Le, T. V., \& Nguyen, L. N. (2017). Analyzing factors affecting FDI of provinces in Vietnam by econometric space. Journal of Economic Development, 28(7), 4-33.

Tintin, C. (2013). The determinants of foreign direct investment inflows in the Central and Eastern European Countries: The importance of Institutions. Communist and PostCommunist Studies, 46(2013), 287-298. DOI: 10.1016/j. postcomstud.2013.03.006

Vu, T. T. A., Le, V. T., \& Vo, T. T. (2007). Provincial Extralegal Investment Incentives in the Context of Decentralisation in Viet Nam: Mutually Beneficial or a Race to the Bottom? Proceedings of UNDP-Vietnam Discussion Papers on Topics Relating to Decentralisation and Economic Performance. The Fulbright Economics Teaching Programme in Ho Chi Minh City and Harvard University's John F. Kennedy School of Government.

Wang, C., \& Balasubramanyam, V. N. (2011). Aid and Foreign Direct Investment in Vietnam. Journal of Economic Integration, 26(4), 721-739. DOI: 10.11130/jei.2011.26.4.721

Xin, O. K., Thye, P. G., Yoke, T. L., \& Chun, P. D. (2012). Factors affecting foreign direct investment decision in Malaysia. A Research Project. Kampar, Malaysia: Universiti Tunku Abdul Rahman. 